\title{
ЗАРИМ ОРДЫН НУУРСНЭЭС ХОЛИМОГ КОКС ГАРГАН АВАХ СУДАЛГАА
}

\author{
Б.Пүрэвсүрэн, С.Жаргалмаа, Б.Бат-Өлзий,У.Баярзул \\ ШУА-ийн Хими, хими технологийн хүрээлэн, НҮүрсний хими технологийн лаборатори
}

Хураангуй

Бид энэхүҮ судалгааны ажлаар нэг талаас коксжих чадвар сайтай нягтарсан хатуу бүтэцтэй Тавантолгой ба Нарийн сухайтын нүүрс нөгөө талаас коксжих чавдаргүй амархан бутардаг сэвсгэр бүтэцтэй Багануурын исэлдсэн хүрэн нүүрсийг сонгон авч эдгээр нүүрсийг дангаар нь болон коксждог ба коксждоггүй нүүрсийг янз бүрийн харьцаагаар хооронд нь хольж коксжих чанарыг нь судлан үүссэн коксын бат бөхийн үзүүлэлтийг тодорхойлов. Энэхүү судалгааны ажлын дүнд холимог кокс дахь хүрэн нүүрсний хэмжээг ихэсгэх дутам холимог коссын бөх бат буурч байгааг тогтоож биежсэн бүхэллэг чанар бүхий холимог кокс гарган авах зохимжтой харьцааг тогтоож сайн чанарын үнэ ихтэй нүүрсийг хэмнэх боломжийг бүрдүүллээ.

\section{Оршил}

Монгол улс нь байгалийн хийн орд илэрцгүй, нефтийн баталгаат нөөц харьцангуй багатай боловч нүүрсний нөөцөөрөө дэлхийд тэргүүлэх орнуудын тоонд багтдаг болно. Манай улс дэлхийд нүүрсээр баялаг арван орны тоонд ордог бөгөөд одоогоор геологийн хайгуулаар 173 тэрбум тонн нүүрсний нөөцтэй хэмээн тогтоогоод байна [1]. Нефть, байгалийн хийн нөөц багасч байгаагаас шалтгаалан нүүрсийг боловсруулан ашиглах нь дэлхийн хэмжээний бодлого боллоо. Хэдийгээр нүүрсний арвин баялаг нөөцтэй боловч манай улс нүүрсийг урьдчилан боловсруулахгүйгээр цахилгаан станц болон айл өрхийн хэрэгцээнд зориулан шууд шатааж хэрэглэж байгаа нь эдийн засгийн хувьд ач холбогдол муутай төдийгүй байгаль орчин, экологид сөргөөр нөлөөлж байгаа ба үүний тодхон жишээ нь Улаанбаатарын агаарын бохирдол юм [2]. Иймд нүүрсийг зүй зохистой, байгаль орчинд ээлтэйгээр ашиглах нь туйлын чухал асуудал болоод байна. Нүүрсийг гүнзгий боловсруулан кокс, хагас кокс, утаагүй түлш, шингээгч материал, шатдаг хий, шингэн түлш, төрөл бүрийн химийн бүтээгдэхүүн гарган авах нь манай улсын импортын хэмжээг багасгах, экспортыг нэмэгдүүлэх, байгаль орчны бохирдлыг бууруулах, химийн үйлдвэрлэлийн шинэ салбарыг хөгжүүлэхэд ихээхэн ач холбогдолтой. Нүүрсний коксжуулалтын процесс нь нүүрсний бөсөх шинж чанараас ихээхэн хамаардаг. Нүүрс бөсөх процесс нь коксжуулалтаас гадна шатаалт, хийжүүлэлт, шингэрүүлэлт гэх мэт дулааны процессын үед явагддаг бөгөөд энэ үед бөсөх чанар нь дээрхи процесуудад сөргөөр нөлөөлдөг [1]. Гадаад оронд сайн чанарын коксждог нүүрсээ хэмнэх үүднээс чанар муутай нүүрстэй тодорхой хэмжээгээр хольж коксжуулан тодорхой хэмжээний бүхэллэг ба бат бөх чанар (өөрөөр хэлбэл ачиж буулгах, зөөх үед бутарч эвдрэхээргүй ) бүхий коксыг гарган авч хэрэглэх тохиолдол байдаг боловч энэ талаар манай оронд хийсэн судалгаа туршилтын ажил байхгүй байгаа юм.

Энэхүу судалгааны ажлын зорилго нь чулуун болон хүрэн нүүрсийг хооронд нь тодорхой харьцаагаар авч коксжих 
шинж чанарыг пластометрийн үзүүлэлтээр тодорхойлж, Үүссэн коксын бат бөхийн Үзүүлэлтийг тодорхойлсоноороо энэХүҮ судалгааны ажлын шинэлэг тал бөгөөд манай оронд анх удаа хийгдэж байгаагаараа онцлог юм.

\section{Судалгааны объект}

Бид уг судалгааны ажилд Тавантолгой, Багануур, Нарийн сухайт гэсэн 3 ордын нүүрсийг авлаа.

\section{Судалгааны ажлын арга зүй}

Судалгааны ажилд шаардлагатай нүүрсний дээжийг стандартын дагуу дундажлан буталж, чичиргээт тээрэм дээр 0,2 мм-ээс дээшгүй ширхэглэлтэй болтол нь нунтаглан аналитик дээжийг бэлтгэв. Судалгаанд нүүрсний техник үзүүлэлтүүдийг холбогдох стандарт аргуудаар, Үүнд: чийгийг УСТ-656-79, үнслэгийг УСТ-652-79, дэгдэмхий бодисыг УСТ-654-79 [3,4]тус тус тодорхойлсон. Стандартын дагуу дундажлан буталсан дээжийг $0.15 \mathrm{Mm}$ ширхэглэлтэйгээр шигшинэ. ЭнэХүY багажийн гол эд ангиудад пластометрийн ган стакан, зүҮ, хэмжүүр, заалтаас бүрдэх пластометр, дээжинд даралт өгөх ачаa, хөшүүрэг, галд тэсвэртэй тоосгоор хүрээлүүлсэн халаагуур, цагийн механизмтай эргэлдэгч бөмбөр болно. Эдгээр нь бүгд металл суурин дээр бэхлэгдсэн байдаг. Нүүрсний пластометрийн үзүүлэлтийг ГОСТ1186 стандартын дагуу тодорхойлно. Пластометрийн аппарат дахь нөхцөл нь үйлдвэрийн коксжуулалтийн нөхцөлтэй нилээд төсөөтэй байдаг. Пластометрийн аппаратыг 1-р зурагт харуулав.

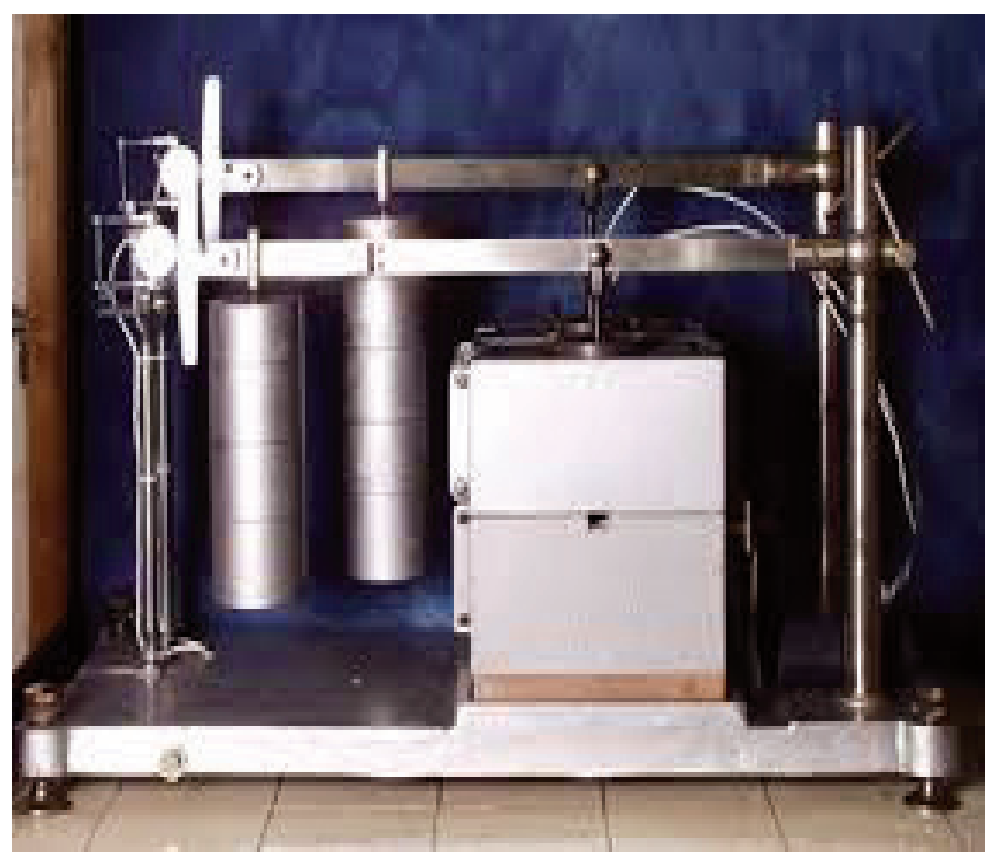

1-р зураг. Пластометрийн аппаратын зураг 
Стаканд агуулагдах нүурс нь ёроолоосоо халах тул нүүрс доороосоо эхлэн коксжих процессд орно. Процесс аажим явагдах тул стаканд буй дээж нь кокс, хагас кокс, уян харимхай масс, хувиралд ороогүй нүүрсний параллель давхаргуудаас бүрдэнэ. Урьдчилан бэлтгэсэн дээжнээсээ 100 граммыг 2 стаканд тус бүрд нь хийж ачаатай хөшүүргэнд бэхэлсэн тагаар хаадаг. Даралтын хэмжээ 1атм. Туршилтын явцад хөшүүргийн үзүүрт бэхэлсэн үзэг нь дээжийн эзлэхүүний өөрчлөлтийг эргэлдэж буй бамбарт автоматаар бичдэг. Туршилт эхэлсэнээс хойш 30 минутын дараа бортогоны ёроолын температур $250^{\circ} \mathrm{C}$ хүрэхээр халаалтын хурдыг тохируулсан байдаг. Үүний дараа халаалтыг $3^{\circ} \mathrm{C} / \mathrm{Mин}$ хурдтайгаар $730^{\circ} \mathrm{C}$ хүртэл өсгөдөг. $350^{\circ} \mathrm{C}$ температураас эхлэн уян харимхайн үеийн дээд ба доод түвшинг пластометрээр хэмжинэ. Пластометрын зүҮ уян харимхай массад шүргэн тэр үед тухайн температурт харгалзах уян харимхай үеийн дээд түвшинг тэмдэглэдэг. Үүний дараа зүүг уян харимхай массын дундуур нэвтрүүлэн хагас коксд тулгаад уян харимхайн үеийн доод түвшинг тэмдэглэдэг. Ойролцоогоор 70 минутын дараа буюу $460^{\circ} \mathrm{C}$-д стаканы ёроолд хатуу үлдэгдэл үүсч эхэлнэ. Уян харимхайн массын зузааныг нүүрс-уян харимхайн масс ба уян харимхай массхагас кокс заагуудын хамгийн их зай нь $\mathrm{y}$, пластометрийн суултийг дээжинд өгөгдсөн ачааны өндрийн байрлалын эцсийн өөрчлөлт х болно. Үүнийг пластометрийн муруйн эхний ба эцсийн түвшний ялгавараар тогтоодог. Пластометрийн муруй нь дээжийн эзлэхүүний өөрчлөлтийг харуулах график дүрс юм. ЭнэхүҮ муруйн хэлбэр нь нүүрсний бөсөх чанарыг илтгэнэ [1]. Жишээ нь Нарийн сухайтын ордын нүүрсний эх дээжийн хувьд пластометрийн муруй дараах байдалаар дүрслэгдсэн байгааг 2-р зурагт харуулав.

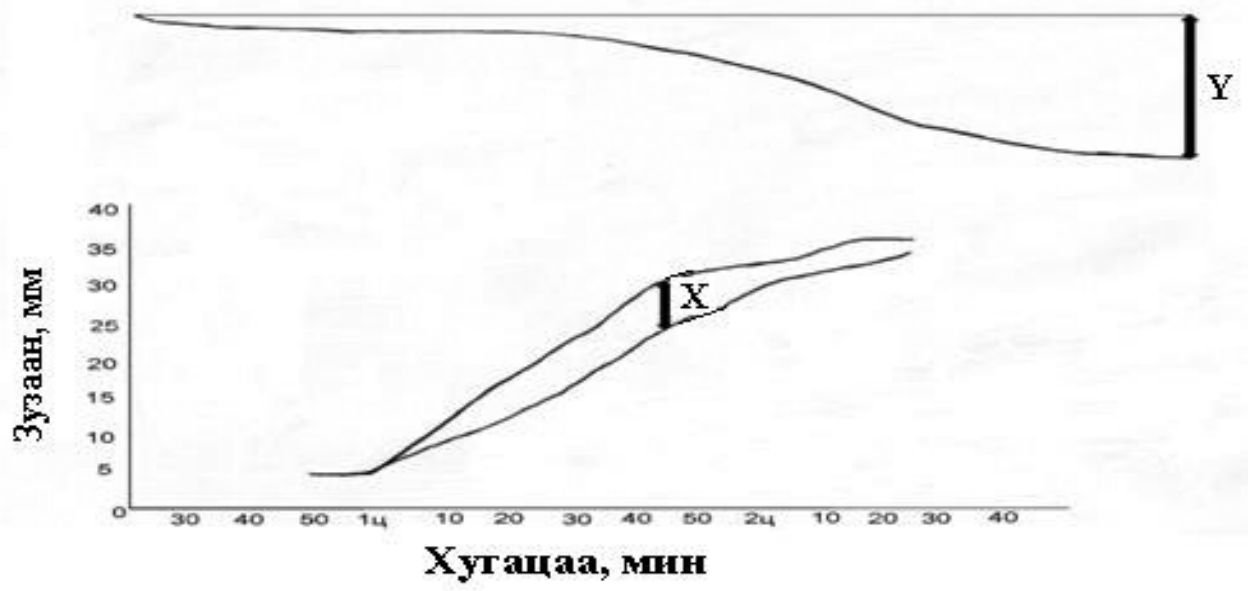

2-р зураг. Нарийн сухайтылн ордын нүҮрсний пластометрийн муруй

Нүүрсний дээжийг пластометрийн аппаратанд халааж хэмжилтийг явуулсны дүнд зэвэрдэггүй ган стаканд Үүссэн коксын бат бөхийн үзүүлэлтийг хэмжихийн тулд түүнээс шоо хэлбэртэйг сорьц бэлтгэнэ. Жишээ болгон авсан Нарийн сухайтын ордын нүүрсний нунтаг эх дээж болон үүссэн коксын хэлбэр, коксыг шоо хэлбэрээр бэлтгэсэн дээжийн зургийг 3-p зурагт харуулав. 


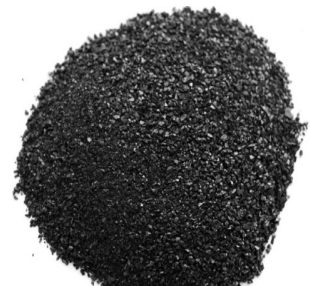

A)

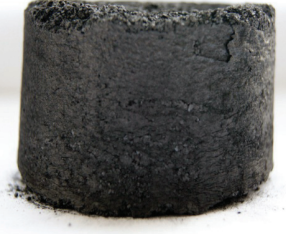

Б)

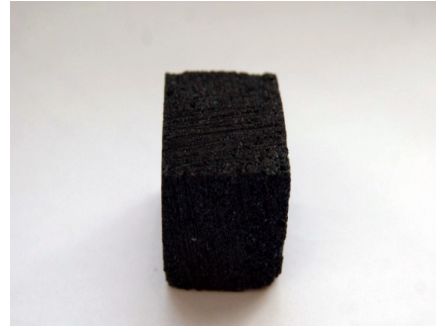

B)

3-р зураг. А) Эх дээж 0,15мм-ээс доош ширхэглэлтэй нүҮрс Б) Пластометрийн аппаратын стаканд ҮҮссэн кокс В) ҮҮссэн коксыг шоо хэлбэртэй бэлтгэсэн дээж

Ингэж бэлтгэсэн сорьцын шахалтын багажинд тодорхойллоо. Энэхүү багажийг бат бөхийн үзүүлэлтийг Jian, WDW-50 4-p зурагт харуулав.

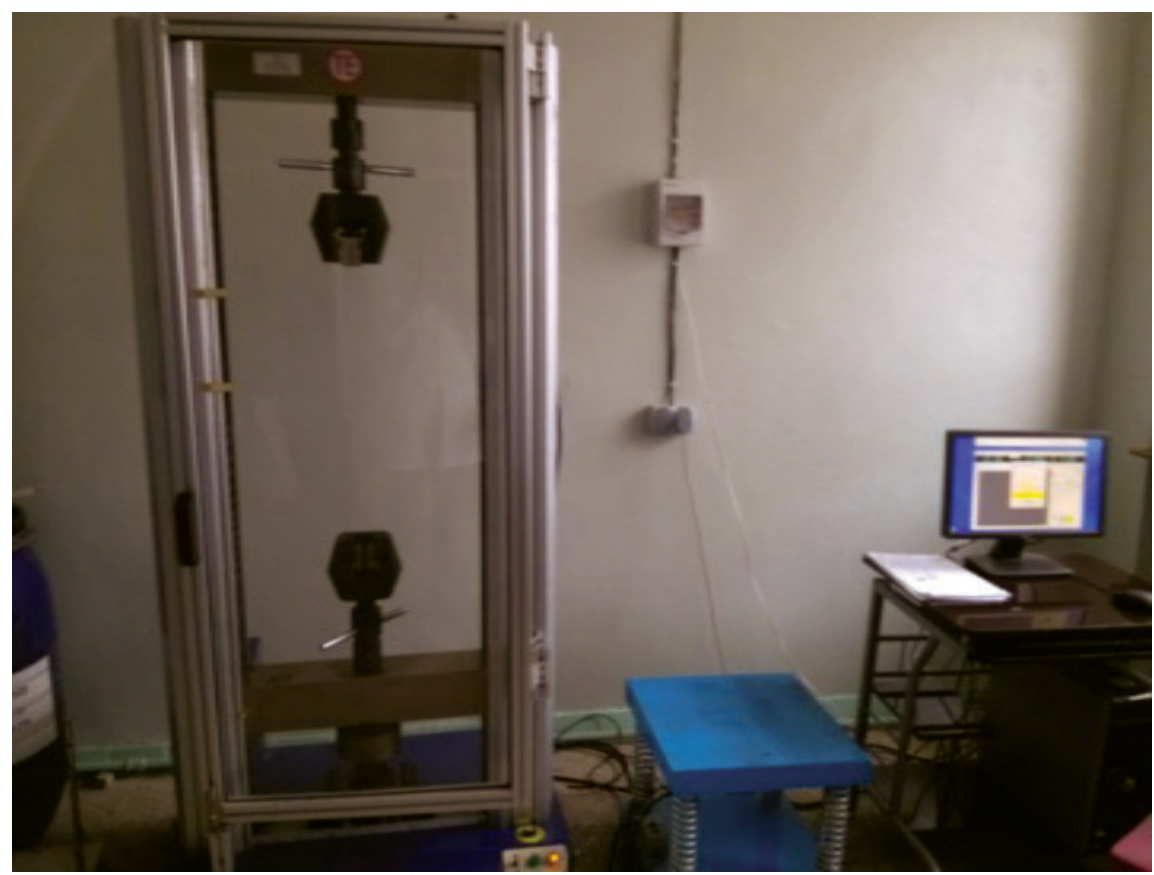

4-р зураг. Шахалтын аппарат

Энэхүу шахалтын багажинд илэрхийлэгдэнэ. Жишээ нь Нарийн дээжийн бат бөхийн үзүүлэлтийг хэмжсэн сухайтын ордын нүүрсний эх дээжийн үр дүн нь 1-р зурагт үзүүлсэн хүч ба хувьд бат бөхийн үзүүлэлтийн графикийг хугацааны муруйны оргил цэгийн утгаар 5-р зурагт үзүүлэв. хэмжигдэх ба дараах графикаар дүрслэгдэн 


\section{Ачааллах хуч, (кH)}

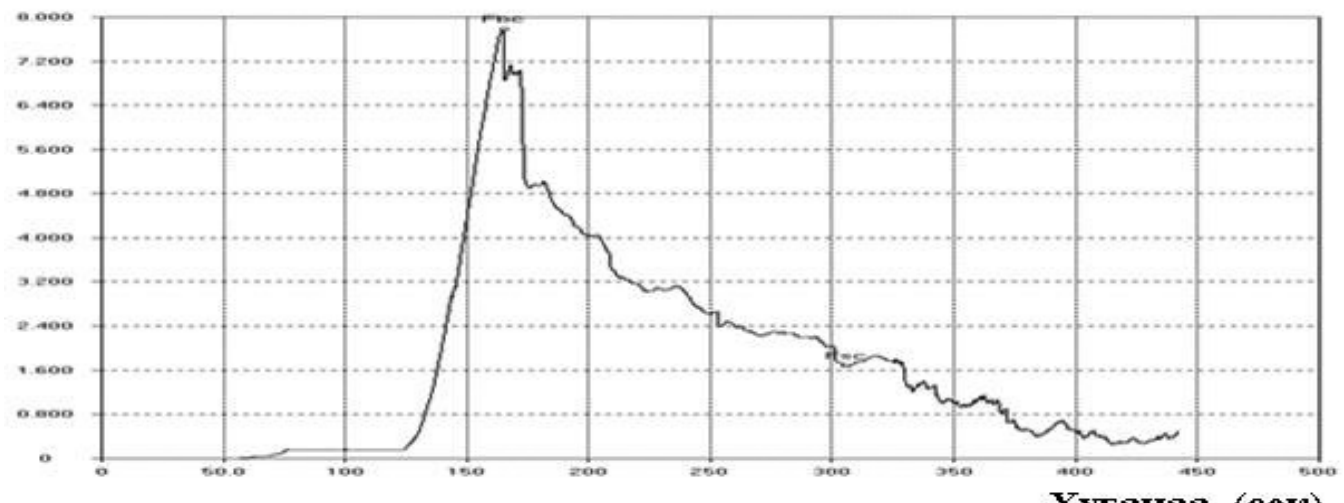

5-р зураг. Нарийн сухайтын ордын нүүрсийн эх дээжийн бат бөхийн үзүүлэлтийн график

\section{Судалгааны үр дүн}

Бид судалгаанд авсан Тавантолгой, үндсэн үзүүлэлтүүдийг дээр дурьдсан Багануур, Нарийн сухайт зэрэг 3 стандартуудын дагуу тодорхойлсон бөгөөд ордын нүүрсний дээжинд техникийн үр дүнг 1-р Хүснэгтэд харуулав.

1-р Хүснэгт. 3 ордын нүҮрсний техник анализын ҮзүҮлэлтүҮд

\begin{tabular}{|c|c|c|c|c|c|c|}
\hline \multirow{2}{*}{ Нүүрсний орд } & \multicolumn{6}{|c|}{ Техникийн үндсэн үзүүлэлтүуд,\% } \\
\cline { 2 - 7 } & $\mathrm{A}^{\mathrm{a}}$ & $\mathrm{A}^{\mathrm{d}}$ & $\mathrm{W}^{\mathrm{a}}$ & $\mathrm{V}^{\mathrm{a}}$ & $\mathrm{V}^{\text {daf }}$ & $\mathrm{Q}$, ккал/кг \\
\hline Тавантолгой & 14.67 & 14.8 & 0.82 & 25.26 & 29.9 & 7524 \\
\hline Багануур & 9.52 & 10.4 & 8.4 & 42.12 & 41.13 & 4757 \\
\hline Нарийн сухайт & 9.14 & 9.25 & 1.24 & 33.20 & 35.66 & 6778 \\
\hline
\end{tabular}

1-р хүснэгтээс харахад Тавантолгойн ордын нүүрс нь чийг багатай, илчлэг өндөртэй дэгдэмхий бодисын гарц харьцангуй бага $29,9 \%$ байгаа нь коксждог чулуун нүүрс болох нь харагдаж байна. Харин Багануурын ордын нүүрс нь илчлэг чанар багатай, дэгдэмхий бодисын гарц ихтэй органик хэсэг нь халуун тэсвэрлэх чадвар муутай хүрэн нүүрс болох нь харагдаж байна. Нарийн сухайтын ордын нүүрсний үнслэгийн хэмжээ харьцангуй багатай, Таван толгойн нүүрстэй харьцуулахад дэгдэмхий бодисын гарц харьцангуй ихтэй байгаа нь чанарын хувьд түүнийг арай гүйцэхгүй боловч мөн л сайн чанарын чулуун нүүрс болохыг харуулж байгаа ба дэгдэмхий бодис тодорхойлсоны дараaх тигель дэхь үлдэгдэл нь хатуу бүхэллэг биежсэн, нүх сүвэрхэг бүтэцтэй байгаа нь коксжих чадвар сайтайг харуулж байна. Харин Багануурын нүүрсний дэгдэмхий бодис тодорхойлсоны дараах тигель дэхь үлдэгдэл нь бүхэллэг биш нунтаг хэлбэртэй байгаа нь бөсөх чанаргүй хүрэн нүүрс болохыг харуулж байгаагаараа нөгөө 2 нүүрснээсээ ялгарч байна.

Таван толгой, Нарийн сухайт, Багануурын нүүрс ба тэдгээрээс гарган авсан хольцуудын коксжих чадварыг пластометрийн аргаар тодорхойлсон дүнг 2-р Хүснэгтэнд үзүүлэв. 
2-р Хүснэгт.Таван толгой, Нарийн сухайт, Багануурын нүүрс ба тэдгээрээс гарган авсан хольиуудын пластометрийн судалгааны дүн.

\begin{tabular}{|c|c|c|c|}
\hline \multirow{2}{*}{ Дээж } & \multicolumn{2}{|c|}{ Пластометр } & \multirow{2}{*}{ Үнслэг, $\mathrm{A}^{\mathrm{d}}$} \\
\cline { 2 - 3 } & $\mathrm{x}$ & $\mathrm{y}$ & \\
\hline Нарийн сухайт $=100: 00$ & 42 & 9 & 11.42 \\
\hline Нарийн сухай : Багануур $=90: 10$ & 36 & 8 & 11.80 \\
\hline Нарийн сухайт : Багануур $=80: 20$ & 43 & 6 & 11.92 \\
\hline Нарийн сухайт : Багануур $=70: 30$ & 47 & 5 & 12.10 \\
\hline Нарийн сухайт : Багануур $=60: 40$ & 48 & 2 & 14.27 \\
\hline Нарийн сухайт : Багануур $=50: 50$ & 45 & 1 & 14.60 \\
\hline Нарийн сухайт : Багануур $=40: 60$ & 52 & 1 & 14.88 \\
\hline Нарийн сухайт : Багануур $=30: 70$ & - & - & 15.80 \\
\hline Нарийн сухайт : Багануур $=20: 80$ & - & - & 16.91 \\
\hline Таван толгойн эх дээж $=100: 00$ & 30 & 21 & 15.05 \\
\hline Тавантолгой : Багануур $=90: 10$ & 47 & 16 & 15.75 \\
\hline Тавантолгой : Багануур $=80: 20$ & 46 & 12 & 15.30 \\
\hline Тавантолгой : Багануур $=70: 30$ & 54 & 11 & 15.60 \\
\hline Тавантолгой : Багануур $=60: 40$ & 58 & 11 & 15.75 \\
\hline Тавантолгой : Багануур $=50: 50$ & 63 & 10 & 15.50 \\
\hline Тавантолгой : Багануур $=40: 60$ & 57 & 6 & 15.40 \\
\hline Тавантолгой :Багануур $=30: 70$ & 58 & 2 & 15.60 \\
\hline Тавантолгой : Багануур $=20: 80$ & - & - & 15.80 \\
\hline
\end{tabular}

2-p хүснэгтээс харахад Нарийн сухайтын дээж нь Тавантолгойн нүүрсний дээжнээс коксжих чанараараа харьцангуй бага байна. Тавантолгойн нүүрсний дээжийг Багануурын нүүрсний дээжтэй тодорхой харьцаагаар холиход үүссэн холимогийн коксжих чанар өөрөөр хэлбэл пластометрийн Үзүүлэлт болох У-ийн хэмжээ нь Тавантолгойн нүүрсний масс багасах тусам буурч байна. Нарийн сухайтын нүүрсний хувьд холимог дахь Нарийн сухайтын нүүрсний масс багасах тусам коксжилт нь Таван толгой ба Багануурын нүүрсний холимогийнхоос эрчимтэй буурч байна. Багануурын нүүрсний агуулга ихсэх тусам нүүрсний кокжих чанар багасаж байна. Тавантолгойн нүүрсний эх дээжийн үнслэг нь 14,8\% пластометрийн дараах коксынх нь үнслэг нь 15,05\%, Нарийн сухайтын нүүрсний хувьд үнслэгийн хэмжээ 9,25-11,42\% хүртэл өссөн нь эх нүүрснүүд халуун задралд орсон нь харагдаж байна. Мөн холимог дахь Багануурын нүүрсний агуулга ихсэх тусам үүссэн коксын үнслэг нь Тавантолгойн нүүрсний хувьд 15.05\%$15.6 \%$ хүртэл, Нарийн сухайтын нүүрсэнд $11,42 \%-16.91 \%$ хүртэл өссөн болох нь хүснэгтээс харадаж байна.

Нарийн сухайт : Багануур $=30: 70$ ба Тавантолгой : Багануур $=20: 80$ харьцаанаас эхлээд холимогууд коксжих чадваргүй болж пластометрийн стакан дахь холимог нь нунтаг хэлбэртэй байдалтай байгаа учраас У-ийн утгыг хэмжих боломжгүй байгаа нь эдгээр харьцаанууд хүртэл холимог кокс бэлтгэж болохыг харуулж байна. Харин гарган авсан холимог коксын бөх батын үзүүлэлт хир зэрэг байх нь чухамхүу яг ямар харицааг зохимжтойд тооцож болохыг тогтоох гол үндэслэл болох юм

Энэ зорилгын үүднээс судалгаанд ашиглагдаж байгаa 3 ордын нүүрсний 
пластометрийн үзүүлэлтийг тодорхойлсон коксыг шоо хэлбэртэй сорьц бэлтгэж бат бөхийн үзүүлэлтийг тодорхойлж үр дүнг 3-р хүснэгтэнд үзүүлэв.

3-р Хүснэгт. Бэлтгэсэн коксон сорьиуудын бат бөхийн ҮзуҮлэлт

\begin{tabular}{|c|c|c|c|}
\hline Дээж & $\begin{array}{c}\text { Бэлтгэсэн шоо } \\
\text { Өргөн:өндөр:урт (мм) }\end{array}$ & $\begin{array}{l}\text { Шооны масс, } \\
\text { (гр) }\end{array}$ & $\begin{array}{l}\text { Бат бөх } \\
{[\mathrm{MPa}]}\end{array}$ \\
\hline Таван толгойн эх дээж = $100: 00$ & $21.89: 16.89: 23.27$ & 6.80 & 22.52 \\
\hline Тавантолгой : Багануур = $90: 10$ & $21.88: 21.01: 20.77$ & 8.10 & 14.22 \\
\hline Тавантолгой : Багануур = 80:20 & $20.98: 20.39: 21.20$ & 7.60 & 12.77 \\
\hline Тавантолгой : Багануур = 70:30 & $21.00: 20.53: 20.80$ & 7.90 & 10.56 \\
\hline Тавантолгой : Багануур = 60:40 & $21.90: 21.55: 20.42$ & 8.90 & 9.04 \\
\hline Тавантолгой : Багануур = 50:50 & $22.26: 22.41: 21.28$ & 10.10 & 8.95 \\
\hline Тавантолгой : Багануур = 40:60 & $22.18: 22.77: 21.11$ & 8.20 & 2.03 \\
\hline Тавантолгой : Багануур = 30:70 & $25.64: 26.24: 2376$ & 8.20 & 0.38 \\
\hline Тавантолгой : Багануур = 20:80 & \multicolumn{3}{|c|}{ Шоо хэлбэртэй сорьц бэлтгэх боломжгүй } \\
\hline Нарийн сухайт эх дээж = 100:00 & $21.63 \times 20.82 \times 21.90$ & 9.75 & 16.30 \\
\hline Нарийн сухайт : Багануур = 90:10 & $21.83 \times 21.72 \times 21.91$ & 9.25 & 3.83 \\
\hline Нарийн сухайт : Багануур = 80:20 & $22.63 \times 21 \times 21.95$ & 8.40 & 2.19 \\
\hline Нарийн сухайт : Багануур = 70:30 & $21.89 \times 19.65 \times 21.8$ & 7.65 & 1.01 \\
\hline Нарийн сухай : Багануур = 60:40 & \multicolumn{3}{|c|}{ Шоо хэлбэртэй сорьц бэлтгэх боломжгүй } \\
\hline Нарийн сухайт : Багануур $=50: 50$ & \multicolumn{3}{|c|}{ Шоо хэлбэртэй сорьц бэлтгэх боломжгүй } \\
\hline Нарийн сухайт : Багануур = 40:60 & \multicolumn{3}{|c|}{ Шоо хэлбэртэй сорьц бэлтгэх боломжгүй } \\
\hline Нарийн сухай : Багануур = 30:70 & \multicolumn{3}{|c|}{ Шоо хэлбэртэй сорьц бэлтгэх боломжгүй } \\
\hline Нарийн сухайт : Багануур = 20:80 & \multicolumn{3}{|c|}{ Шоо хэлбэртэй сорьц бэлтгэх боломжгүй } \\
\hline
\end{tabular}

2-р Хүснэгтэнд үзүүлсэнээр Нарийн сухайт : Багануур $=30: 70$ ба Тавантолгой : Багануур $=20: 80$ харьцаанаас эхлээд холимогууд коксжих чадваргүй болж байсан бол 3-р Хүснэгтэнд үзүүлснээр үүнийг баталж эдгээр холимогуудаас шоо хэлбэртэй сорьц бэлтгэх боломжгүй учир бат бөхийн үзүүлэлтүүдийг үзэх боломжгүй байгаа юм.

Дээрхи судалгааны үр дүнгээс харахад холимог дахь хүрэн нүүрсний агуулга ихсэх тусам бат бөхийн үзүүлэлт буурсан байна. Коксждог нүүрс тус бүрийн эх дээж ба холимог коксын бат бөхийн үзүүлэлтийн үр дүнг 6 ба 7-p Зурагуудад тус тус үзүүлэв.

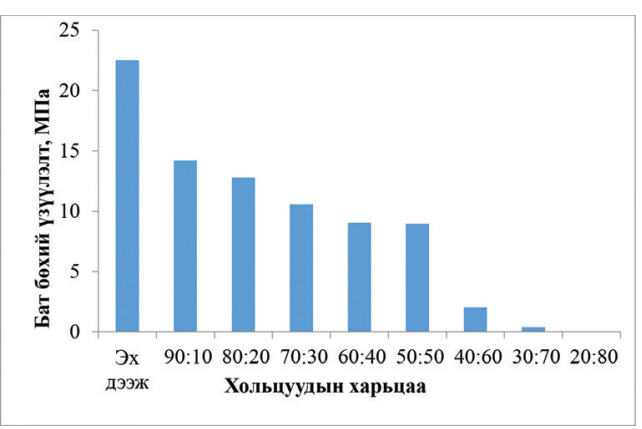

6-р зураг. Тавантолгойн нүҮрсний эх дээжний болон Багануурын нүүрстэй хольсон нүүрсний коксын бат бөхийн Үзүүлэлт.

6-p зургаас харахад Тавантолгойн нүүрсний эх дээжний бат бөхийн үзүүлэлт нь 22,52 МПа ба Багануурын нүүрстэй тодорхой харьцаагаар хольсон нүүрсний 
коксын бат бөхийн үзүүлэлт нь ерөнхийдөө буурсан зүй тогтол ажиглагдлаа. Энэ нь хольц дахь хүрэн нүүрсний хэмжээ ихсэх тусам бат бөхийн үзүүлэлт буурч байгаа зүй тогтолыг харуулж байна. Иймд Таван толгой ба Багануурын нүүрсийг 80:20-иос $60: 40$-ийн хооронд холиход үүссэн холимог коксын бөх батын хэмжээ боломжийн хэмжээнд өөрөөр хэбэл 9,00 12,77 МПа байна. Энэ дүнгээс үндэслээд бид Таван толгой ба Багануурын нүүрснээс холимог кокс бэлтгэх хамгийн зохимжтой харьцааг $70: 30$ гэж сонгон үүссэн коксын бат бөх нь боломжийн гэж үзлээ.

7-р зургаас харахад Нарийн сухайтын нүүрсний эх дээжний коксын бат бөхийн үзүҮлэлт нь 16.3МПа нь Таван толггойн нүүрсний коксныхоос бага байгаа мөн дээр 2-р Хүснэгтэнд үзүүлснээр коксжих чадвар нь мөн адил бага байгаа зэргээс хамаараад Нарийн сухайт ба Багануурын холимог коксын бөх батын үзүүлэлт маш эрчимтэй буурч байгаагаас Үзэхэд холимог кокс

\section{Дүгнэлт}

1.Тавантолгойн ордын нүүрс нь чийг багатай, илчлэг өндөртэй дэгдэмхий бодисын гарц 29,9\% чулуун нүүрс болох нь харагдаж байна. Харин Багануурын ордын нүүрс нь дэгдэмхий бодисын гарц ихтэй органик хэсэг нь халуун тэсвэрлэх чадвар муутай хүрэн нүүрс болох нь харагдаж байна.

2.Нарийн сухайтын нүүрсний дэгдэмхий бодисын гарц нь Тавантолгойн нүүрсний дээжнийхээс нилээд их байгаа нь Нарийн сухайтын нүүрсний коксжих чанар нь Тавантолгойн нүүрснээс бага болохыг илэрхийлж байна.

3.Тавантолгой болон Нарийн сухайтын нүүрсүүдийн коксжилт үүсэхгүй үеийн хольцын харьцаа нь Тавантолгой болон Багануурын нүүрсний хувьд 30:70, харин Нарийн сухайт Багануурын нүүрсний хувьд 20:80 харьцаатай болохыг тогтоов.

4. Таван толгой ба Багануурын бэлтгэх боломж Таван толгойн нүүрстэй харьцуулахад их бага байна.

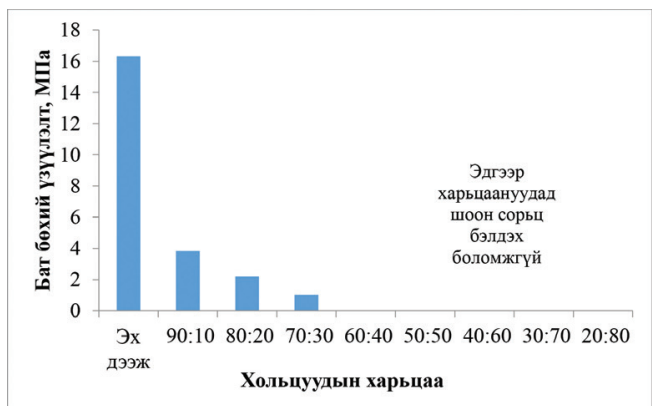

7-р зураг. Нарийн сухайтын нүүрсний эх дэээ ба Багануурын нүүрстэй хольсон нүүрсний коксын бат бөхийн үзүҮлэлт.

Нарийн сухайт ба Багануурын нүүрснээс холимог кокс бэлтгэх зохимжтой харьцааг $90: 10$ гэж үзвэл үүссэн коксын бат бөх нь ямар нэг хэмжээгээр тодорхой хэрэгцээний шаардлагыг хангаж болох юм гэж үзлээ.

нүүрснээс холимог кокс бэлтгэх хамгийн зохимжтой харьцааг $70: 30$ гэж сонгон Үүссэн коксын бат бөх нь боломжийн гэж үзлээ.

5. Нарийн сухайт ба Багануурын нүүрснээс холимог кокс бэлтгэх зохимжтой харьцааг $90: 10$ гэж үзвэл үүссэн коксын бат бөх нь ямар нэг хэмжээгээр тодорхой хэрэгцээний шаардлагыг хангаж болох юм гэж үзлээ.

6.Коксждог чулуун нүүрсийг хүрэн нүүрстэй тодорхой харьцаагаар хольж бэлтгэсэн холимогийн коксжих чадварыг пластометрийн аргаар судалж Үүссэн коксын бат бөхийн үзүүлэлтийг тодорхойлсон дүнгээс үзэхэд холимог дахь хүрэн нүүрсний хэмжээ ихсэх дутам холимогийн коксжих чадвар мөн үүссэн холимог коксын бат бөхийн үзүүлэлт мөн нь буурч байна. 


\section{Аиигласан бүтээлийн жсагсаалт}

1. Ж.Нарангэрэл, "НҮҮрсний хими, технологийн үндэс", Улаанбаатар, “Адмон” ХХК, 2011. x. 388

2. Б.Пүрэвсүрэн, Я.Даваажав, Р.Эрдэнэчимэг, “Монгол орны зарим томоохон ордын нҮҮрсний судалгаа”, Улаанбаатар, 2010. х.212.

3. Межгосударственный стандарт, ГОСТ 2408.1-95 (ИСО 625-96). Топливо твердое. Методы определения углерода и водорода. Минск. 2000 г.

4. Межгосударственный стандарт, ГОСТ 2408.3-95 (ИСО 1994-76). Топливо твердое. Методы определения кислорода, Минск 1997 2. 


\title{
INVESTIGATION ON PREPARATION OF MIXED COKE FROM COALS
}

B.Purevsuren, S.Jargalmaa, B.Batulzii, U.Byarzul Institute of Chemistry and Chemical Technology, Mongolian Academy of Sciences.

\begin{abstract}
High quality coking coals of Tavan tolgoi and Nariin sukhait and brown coal of Baganuur deposits have been investigated for preparation of mixed coke and characterized coking ability and strength of mixed coke samples at different mass ratio. Have been determined an optimal mass ratio between coking coal and brown coal which allows to save expensive and high quality coal. The coking property and strength of mixed coke decreased by increasing mass of low quality brown coal.
\end{abstract}

